\title{
EFEKTIVITAS MODUL ESTIMASI BIAYA KONSTRUKSI JALAN PADA MATA PELAJARAN ESTIMASI BIAYA KONSTRUKSI DI SMK N 1 PURWOREJO
}

\author{
Sumardjo ${ }^{1}$, Galeh Nur Indriatno Putra Pratama ${ }^{2}$, dan Turas Nur Vemantyasto ${ }^{3}$ \\ ${ }^{1,2,3}$ Pendidikan Teknik Sipil dan Perencanaan, FT, UNY \\ Email: galeh@uny.ac.id
}

\begin{abstract}
ABSTRAK
Tujuan kajian ini adalah:(1) mengetahuitahap pengembangan modul estimasibiaya konstruksijalanpada mata pelajaran Es timasi Biaya Konstruksi dan (2) mengetahui tingkat kelayakan modul estimasi biay akonstruksi jalan pada mata pelajaran Estimasi Biaya Konstruksi untuk sis wa kelas XI kompetensi keahlianDesainPemodelan dan Informasi Bangunan SMK Negeri 1 Purworejo. Pendekatan yang digunakan dalamkajian iniadalah Research and Development. Des ain kajian ini menggunakan 4D (four-D) Thiagarajan dengan empat tahapan pokok, yaitu: Define (pendefisian); Design (perancangan); Develop (pengembangan); dan Disseminate (penyebaran).Teknik pengumpulan data melalui angket dengan didukung oleh observasidan wawancara. Teknik analis is data yang digunakan adalah analis is des kriptif dengan cara mengolah data kuantitatif yang kemudian ditafs irkan menjadi data kualitatif. Hasil kajian menunjukkan bahwa:(1) pengembangan modul pada tahap definemenunjukkanbelum ters edianya modulestimasi biaya konstruksijalan, pada tahap design moduldis us un sesuai deng ankompetensi dan tujuan pembelajaran yang telah dibuat, pada tahap develop adanya saran dariahli materi mengenairuntutan materi perlu dibuat lebih terstruktur dan sis tematis dilain itu adanya saran dariahli media mengenai perbaikan penulisan indek tabel dan gambar serta posisi penulisan konten pada halaman landscape, dan pada tahap disseminate penyebaran moduldilakukan kepada guru mata pelajaran Estimasi Biaya Konstruksi; (2)tingkat kelayakan modulestimasi biaya kons truksijalan menurut ahlimateri diperoleh persepsi kelayakan sebesar3,425 dengan kategori sangat layak, menurut ahli media diperoleh persepsi kelayakan sebes ar 2,96 dengan kategori layak, dan menurut guru sebagai pengguna diperoleh persepsi kelayakan s ebesar 4 deng an kategori sangat layak.
\end{abstract}

Kata kunci: Estimasi biaya konstruksi, Modul, SMK

\section{ABSTRACT}

This study aims to reveal how: (1) knowing the development stage of the roadconstructioncostestimation module in the Construction Cost Estimation subject and (2) knowing the feasibilityleveloftheroadconstruction cost estimation module in the Construction Cost Estimation subject for class XI students of competency in Modeling and Information Design expertise Building ofSMK Negeri 1 Purworejo.Theapproachusedinthisstudy is Research and Development. The design of this study uses the 4D(four-D) Thiagarajan with fourmainstages, namely: Define; Design; Development; and Disseminate. The technique of collecting datathroughaquestionnaire is supported by observation and interviews. The data analysis technique usedisdescriptiveanalysisbyprocessing quantitative data which is then interpreted into qualitative data. The resultsofthestudyshowthat:(1)Developing module in stage define show unavailability module is the estimated cost of construction ofroads, instagedesign module prepared in accordance with the competencies and learning objectives that have been made, instage develop the advice ofmaterial expert on sequence of the material needs to be mademorestructuredandsystematic on the other hand the advice ofmedia expert on improving writing tables and figure sindexaswellastheposition of the writing of content on the page landscape, and at the stage disseminate deploymentofthemoduleisdoneto the Estimasi Biaya Konstruksi subject teacher; (2) Level fea sibility of road construction cost estimatemodule according to material expert obtained a feasibility perception of 3,425 with a veryfeasiblecategory, according to media expert obtained a fea sibility perception of 2.96 with a feasible category, andaccordingtoteacherasauser obtained a feasibility perception of 4 with a very feasible category.

Keywords: Construction cost estimate, Module, SMK 


\section{Efektivitas Modul Estimasi ... (Sumardjo/ hal. 104-116)}

\section{PENDAHULUAN}

Pendidikan menengah kejuruan adalah pendidikan pada jenjang pendidikan menengah yang mengutamakan pengembangan kemampuan siswa untuk melaksanakan jenis pekerjaan tertentu (Peraturan Pemerintah RI Nomor 29 Tahun 1990 tentang Pendidikan Menegah). Berdasarkan definisi tersebut, maka Sekolah Menegah Kejuruan merupakan lembaga pendidikan yang bertujuan mempersiapkan peserta didiknya untuk mampu menjadi manusia yang produktif, bekerja mandiri, siap berkompetisi, dan dapat beradaptasi di lapangan kerja. Tercapai tidaknya tujuan tersebut sangat tergantung pada sejumlah variabel dalam proses pendidikan.

Dalam rangka mewujudkan keterampilan pengetahuan abad ke-21, Kementerian Pendidikan dan Kebudayaan menerapkan Kurikulum 2013 Revisi 2017 yang merupakan hasil perbaikan dari kurikulum sebelumnya yaitu Kurikulum 2013. Kurikulum 2013 Revisi 2017 tidak hanya menekankan kepada pengusaan kompetensi siswa, melainkan juga pembentukkan karakter. Dengan adanya Kurikulum 2013 Revisi 2017 tersebut diharapkan peserta didik menjadi lebih aktif dalam proses pembelajaran serta mentuntut perserta didik mencapai kemandirian dalam belajar. Dimana yang awalnya berpusat pada guru berubah menjadi berpusat pada peserta didik. Keberhasilan implementasi Kurikulum 2013 Revisi 2017 tentunya dipengaruhi oleh berbagai faktor. Faktorfaktor tersebut antara lain berkaitan dengan kepemimpinan kepala sekolah, guru, siswa, fasilitas dan sumber belajar serta lingkungan yang kondusif dan partisipasi wali murid.

Sumber belajar merupakan salah satu variabel yang mempengaruhi tercapai atau tidaknya tujuan pendidikan yang telah disematkan dalam Kurikulum 2013 Revisi 2017. Sumber belajar sangat berpengaruh dalam keberhasilan peserta didik untuk mencapai kompetensi dasar yang diajarkan. Dengan adanya sumber belajar yang baik dan valid membuat proses pembelajaran lebih mudah untuk dipahami. Sejalan dengan Kurikulum 2013 Revisi 2017 yang mempresentasikan student centered yaitu peserta didik dituntut aktif dan mandiri untuk mengelaborasi informasi yang diperoleh dalam memecahkan persoalan.

Dari hasil observasi di SMK Negeri 1

Purworejo kompetensi keahlian Desain Pemodelan dan Informasi Bangunan kelas XI menunjukakan belum terlaksananya dan tercapainya tujuan dari penerapan Kurikulum 2013 Revisi 2017. Pernyataan ini didukung dengan kurang memadainya sumber belajar yang digunakan dalam proses pembelajaran. Pada mata pelajaran Estimasi Biaya Konstruksi sesuai dengan isi dari Kompetensi Inti dan Kompetensi Dasar pada Kurikulum 2013 Revisi 2017 SMK tertulis bahwa untuk mata pelajaran Estimasi Biaya Konstruksi kompetensi keahlian Desain Pemodelan dan Informasi Bangunan kelas XI mempelajari mengenai estimasi biaya konstruksi gedung, jalan, dan jembatan. Namun pada kenyataanya di lapangan sumber belajar yang tersedia hanya mengulas mengenai estimasi biaya konstruksi gedung saja. Penulis juga menilai bahwa isi bahan ajar yang sudah ada masih terdapat banyak kekurangan seperti materi yang kurang lengkap dan soal latihan yang belum tersedia.

Kurang tersedianya sumber belajar pada mata pelajaran Estimasi Biaya Konstruksi membuat siswa hanya terfokus pada materi yang disampaikan oleh guru. Kecenderungan tersebut mengakibatkan 
Efektivitas Modul Estimasi ... (Sumardjo/ hal. 104-116)

proses belajar mengajar bersifat teacher centered. Hal tersebut membuat kurangnya kemampuan berfikir kritis pada peserta didik dikarenakan pendekatan belajar yang berpusat pada guru. Sehingga peserta didik hanya tergantung pada guru dalam menerima materi dan tidak mencari sumber pembelajaran secara mandiri.

Dalam penerapannya di lapangan sangat sulit untuk menerapkan seluruh materi sesuai KI KD pada mata pelajaran Estimasi Biaya Konstruksi. Hal ini disebabkan karena ruang lingkup materi yang terlalu luas untuk membahas ketiga subbab pada estimasi biaya konstruksi gedung, jalan, dan jembatan. Terlebih lagi dalam memahami dan menerapkan estimasi biaya konstruksi peserta didik memerlukan banyak soal-soal latihan yang harus dikerjakan sebagai bahan uji coba dan evaluasi. Kebutuhan akan media pembelajaran yang dapat digunakan di dalam kelas maupun di rumah merupakan salah satu solusi. Media pembelajaran tersebut diharapkan dapat menambah pemahaman siswa dan menjadikan siswa menjadi mandiri dan aktif dalam pembelajaran.

Permasalahan di atas membuat tidak tercapainya kompetensi keahlian yang telah dicanangkan pada Kurikulum 2013 Revisi 2017 secara maksimal. Sumber belajar yang kurang memadai memaksa siswa untuk mengakses materi dari internet yang masih belum tau kevaliditasannya antara isi bacaan di internet dengan teori sebenarnya di lapangan. Materi yang didapatkan sebagai bahan ajar mata pelajaran Estimasi Biaya Konstruksi mengenai subbab jalan dan jembatan hanya diperoleh dari internet dan materi pelatihan sertifikasi. Sedangkan untuk materi yang diperoleh dari internet tidak bisa dijadikan acuan pokok dikarenakan masih belum tahu kevaliditasannya.

Media dalam Kamus Besar Bahasa Indonesia (KBBI) adalah alat, sarana, perantara atau penghubung yang digunakan untuk komunikasi. Menurut Susilana dan Riyana (2009: 6) media secara harfiah mempunyai arti perantara atau pengantar. Sesuai dengan kebutuhan proses pembelajaran, dibutuhkan alat komunikasi yang dapat menjadi perantara menyampaikan ilmu dari guru ke peserta didik. Media merupakan bagian dari komponen pembelajaran, manfaat dan fungsi media dalam pembelajaran sangat dirasakan baik oleh tenaga pendidik maupun siwa. Keberhasilan media dalam meningkatkan kualias belajar siwa ditentukan pada bagaimana kemampuan guru dalam memilih media yang akan digunakan (Mahnun, 2012: 33). Media yang digunakan dalam proses pembelajaran tersebut di sebut media pembelajaran.

Media pembelajaran menurut Sanaky (2009: 4) adalah sarana pendidikan yang dapat digunakan sebagai perantara dalam proses pembelajaran untuk mempertinggi efektivitas dan efisiensi dalam mencapai tujuan pengajaran. Segala sesuatu yang dapat digunakan untuk menyalurkan pesan yang dapat merangsang pikiran, perasaan, perhatian, dan kemauan peserta didik untuk belajar merupakan media pembelajaran (Miarso, 1989 dalam Susilana \& Riyana, 2009: 6). Seperti yang disampaikan Amir (2014: 80) media pembelajaran adalah suatu perantara yang digunakan oleh pendidik untuk menyalurkan pesan atau informasi kepada peserta didiknya, agar peserta didik tersebut dapat terangsang ketika mengikuti kegiatan pembelajaran.

Modul merupakan bahan ajar yang disusun secara sistematis dengan bahasa 


\section{Efektivitas Modul Estimasi ... (Sumardjo/ hal. 104-116)}

yang mudah dipahami oleh siswa, sesuai usia dan tingkat pengetahuan mereka agar mereka dapat belajar secara mandiri dengan bimbingan minimal dari pendidik (Prastowo, 2015: 106). Pandangan serupa juga dikemukakan oleh Sukiman (2012: 131) yang menyatakan bahwa modul adalah bagian kesatuan belajar yang terencana yang dirancang untuk membantu siswa secara individual dalam mencapai tujuan belajarnya. Sedangkan menurut Susilana dan Riyana (2009: 15) modul merupakan suatu paket program yang disusun dan didesain sedemikian rupa untuk kepentingan belajar siswa. Berdasarkan pendapat-pendapat di atas dapat disimpulkan bahwa modul merupakan paket program yang disusun dan didesain sedemikian rupa sebagai bahan belajar mandiri untuk membantu siswa menguasai tujuan belajarnya.

Modul hendaknya disusun dalam format yang mudah dipelajari dan sistematis, sehingga memudahkan peserta didik untuk mempelajarinya. Berikut adalah salah satu contoh format modul yang dikembangkan dengan memperhatikan kebutuhan pembaca akan keteraturan strukturnya.

Kelayakan modul pembelajaran merupakan kepantasan suatu modul pembelajaran untuk digunakan sebagai media pembelajaran setelah mendapatkan penilaian dari pakar serta diujikan langsung kepada siswa. Untuk mendapatkan modul yang layak digunakan sebagai bahan ajar, maka penilaian modul harus ditentukan berdasarkan aspek atau kriteria yang jelas.

Estimasi biaya konstruksi adalah suatu proses utama dalam proyek untuk mengetahui berapa besar dana yang harus disediakan untuk sebuah bangunan. Sebagai dasar untuk membuat sistem pembiayaan dalam sebuah proyek, estimasi juga digunakan untuk merencanakan jadwal konstruksi (Ervianto, 2005: 129). Dengan adanya estimasi biaya konstruksi harga bagian/item pekerjaan sebagai pedoman untuk mengeluarkan biaya-biaya dalam masa pelaksanaan dapat diketahui. Selain itu supaya bangunan yang akan didirikan dapat dilaksanakan secara efektiv dan efisien.

Mata pelajaran Estimasi Biaya Konstruksi merupakan mata pelajaran yang terdapat pada kurikulum 2013 Revisi 2017. Mata pelajaran ini tergabung dalam kelompok paket C3 pada Kompetensi Keahlian Desain Pemodelan dan Informasi Bangunan di SMK Negeri 1 Purworejo. Mata pelajaran Estimasi Biaya Konstruksi diajarkan pada Kelas XI pada semester ganjil dan genap. Dalam Kurikulum 2013 revisi 2017, materi pelajaran Estimasi Biaya Konstruksi tersusun dari perhitungan estimasi biaya pada gedung, jalan dan jembatan. Berikut kompetensi dasar mata pelajaran Estimasi Biaya Konstruksi.

Ibrahim (2009: 3) berpendapat, yang dimaksud dengan Rencana Anggaran Biaya (Begrooting) suatu bangunan atau proyek adalah perhitungan banyaknya biaya yang diperlukan untuk bahan dan upah serta biaya-biaya lain yang berhubungan dengan pelaksanaan bangunan atau proyek tersebut. Sedangkan menurut Nugroho dan Suryaningrum (2018: 136) Rencana Anggaran Biaya atau RAB adalah perhitungan biaya yang dibutuhkan untuk mengerjakan suatu proyek. Sejalan dengan pendapat sebelumnya menurut Djojowirono (1984) dalam Nugroho dan Suryaningrum (2018: 144) Rencana Anggaran Biaya merupakan perkiraan biaya yang diperlukan untuk setiap pekerjaan dalam suatu proyek konstruksi sehingga akan diperoleh biaya total yang diperlukan untuk menyelesaikan suatu proyek. 
Nugroho dan Suryaningrum (2018: 137) berpendapat, Rencana Anggaran Biaya berfungsi untuk mengetahui estimasi atau perkiraan biaya total yang dibutuhkan untuk menyelesaikan proyek tersebut. Selain itu RAB berfungsi sebagai bahan acuan dasar pelaksanaan proyek. Mulai dari pemilihan kontraktor yang sesuai, pembelian bahan bangunan hingga pengawasan proyek sehingga dapat berjalan sesuai kesepakatan awal dengan pihak kontraktor. Bila tidak disertai RAB ditakutkan akan terjadi pembengkakan biaya.

Fitriyati, U., Mufti, N. \& Lestari, U. (2015), meneliti tentang "Pengembangan Modul Berbasis Riset Pada Mata Kuliah Bioteknologi’. Tujuan penelitian ini adalah menghasilkan modul produk bahan ajar berupa modul berbasis riset yang memuat teknik dan hasil riset uji antiproliferatif partikel $\mathrm{ZnO}$ dan penyinaran UV terhadap sel kanker MCF-7 secara in vitro untuk matakuliah Bioteknologi. Model pengembangan yang digunakan dalam penelitian ini adalah model pengembangan Thiagarajan (4D) yang terdiri dari tahap define, design, develop, dan disseminate, namun tahap penelitian yang dilakukan hanya sampai tahap develop. Hasil validasi dari ahli materi menyatakan tingkat validitas dengan persentase $90,91 \%$, ahli media dan desain pembelajaran 95,83\%, dan uji kelompok kecil 88,89\%. Dapat disimpulkan bahwa modul teknik kultur jaringan hewan berbasis riset uji antiproliferatif partikel $\mathrm{ZnO}$ dan penyinaran UV terhadap sel kanker payudara MCF-7 telah dihasilkan dan telah layak digunakan karena sudah tervalidasi.

Yuwono, K.T. \& Suprapto (2011), meneliti tentang "Pengembangan Modul Praktikum Mikrokontroler (AVR) Menggunakan Perangkat Lunak Proteus Professional v7.5 SP3". Penelitian ini merupakan penelitian rancang bangun melalui tahap analisis kebutuhan, desain, implementasi dan pengujian. Pengujian kerja modul menggunakan alpha testing dan pengujian kelayakan modul menggunakan beta testing sesuai kaidah rekayasa perangkat lunak. Teknik analisis data dengan analisis deskriptif, pemakaian skala likert uji instrumen yang kemudian dideskripsikan dalam pengertian kualitatif. Uji kelayakan/kemanfaatan modul dikaegorikan cukup layak, dengan catatan item kelancaran teknik saat digunakan dan item tingkat fleksibelitas untuk dimodifikasi pada kategori layak prosentasenya tidak terlalu tinggi.

\section{METODE}

Kajian ini menggunakan pendekatan research and development atau $\mathrm{R} \& \mathrm{D}$. Menurut Sugiyono (2016: 427) metode penelitian dan pengembangan (Research and Development) merupakan metode penelitian yang digunakan untuk menghasilkan produk tertentu dan menguji dampak dari produk media tersebut. Tujuan dari kajian ini yaitu untuk mengembangkan dan menghasilkan modul estimasi biaya konstruksi jalan sebagai media pembelajaran mata pelajaran Estimasi Biaya Konstruksi kompetensi keahlian Desain Pemodelan dan Informasi Bangunan kelas XI di SMK Negeri 1 Purworejo.

Kajian ini mengacu pada model penelitian dan pengembangan 4D. Menurut Thiagarajan (1974: 5) dalam pengembangan pembelajaran digunakan model yang disebut Four-D Model (4D), yakni define (pendefinisian), design (desain), develop (pengembangan), disseminate (pendesiminasian). 


\section{Efektivitas Modul Estimasi ... (Sumardjo/ hal. 104-116)}

Subjek kajian adalah sumber informasi atau ahli yang akan memberikan masukan/saran untuk memperoleh data yang diperlukan dan sesuai dengan tujuan kajian. Subjek kajian ini adalah ahli materi, ahli media dan pengguna. Sedangkan uji modul dilakukan melalui uji kelayakan ahli materi dan uji kelayakan ahli media.

\section{HASIL DAN PEMBAHASAN}

Pengembangan media pembelajaran berupa modul untuk peserta didik kelas XI kompetensi keahlian Desain Pemodelan dan Informasi Bangunan SMK Negeri 1 Purworejo dikembangkan menggunakan adaptasi model pengembangan 4D (four-D) yang terdiri atas empat tahap, yaitu pendefinisian (define), perancangan (design), pengembangan (develop), dan penyebaran (dissemination).

Dalam tahapan pertama (define) pengembangan media pembelajaran modul ini, diperoleh data berupa informasi hasil analisis melalui beberapa tahapan berikut: pertama, analisis mengenai karakteristik siswa dalam proses pembelajaran estimasi biaya konstruksi. Hasil dari observasi pada proses pembelajaran diketahui bahwa kurangnya kemampuan berfikir kritis pada peserta didik dikarenakan pendekatan belajar berpusat pada guru/teacher centered. Hal tersebut ditunjukkan ketika proses pembelajaran siswa hanya mendengarkan penjelasan dan mencatat penjelasan guru. Serta terjadinya ketergantungan peserta didik terhadap guru dalam menerima materi dan mengakibatkan peserta didik tidak berinisiatif mencari sumber pembelajaran secara mandiri. Selain itu juga ketika proses pengerjaan soal/tugas banyak peserta didik yang menunggu temannya selesai mengerjakan kemudian melihat langkah- langkah pengerjaan dari pekerjaan temannya.

Kedua, secara umum kompetensi dasar mata pelajaran Estimasi Biaya Konstruksi untuk kompetensi keahlian Desain Pemodelan dan Informasi Bangunan SMK menurut Kurikulum 2013 Revisi 2017 diaplikasikan pada gedung, jalan, dan jembatan. Namun pada kajian ini memfokuskan kompetensi modul hanya ditujukan untuk estimasi biaya konstruksi jalan. Ketiga, perumusan tujuan pembelajaran didasarkan pada analisis tugas dan analisis konsep. Adapun rumusan tujuan pada modul estimasi biaya konstruksi jalan ini adalah membantu memudahkan peserta didik dan guru dalam mempelajari dan mengajarkan estimasi biaya konstruksi jalan secara mandiri.

Tahapan design bertujuan untuk merancang produk yang akan dikembangkan. Produk awal harus memperhatikan kelayakan agar dapat digunakan di lapangan. Tahap perancangan ini meliputi empat tahapan, antara lain: pertama, penyusunan kriteria tes berfungsi sebagai analisis awal untuk mengetahui kemampuan awal peserta didik, dan sebagai alat evaluasi setelah implementasi kegiatan dalam hal pencapaian kompetensi yang ingin dicapai. Namun dikarenakan waktu kajian berlangsung di tahun ajaran baru dengan kata lain peserta didik belum mengusai/memahami materi dengan baik sehingga tes awal tidak dapat dijadikan sebagai patokan. Pengkaji menjadikan observasi dan wawancara guru mata pelajaran sebagai dasar informasi awal.

Kedua, pemilihan media disesuaikan dengan tujuan pembelajaran dan masalah yang ada pada pembelajaran. Berdasarkan uraian tersebut maka Pengkaji mejadikan media berupa modul pembelajaran yang 
disusun secara spesifik, interaktif, dan mendetail sebagai media yang sesuai dengan permasalahan di SMK Negeri 1 Purworejo Kompetensi keahlian Desain Pemodelan dan Informasi Bangunan Mata Pelajaran Estimasi Biaya Konstruksi Kelas XI.

Ketiga, penyusunan format materi dalam modul pembelajaran disusun berdasarkan teori Prastowo (2013: 142) yang disesuaikan dengan kebutuhan dan materi untuk modul. Pengembangan modul Estimasi Biaya Konstruksi Jalan mata pelajaran Estimasi Biaya kelas XI Desain Pemodelan dan Informasi Bangunan (DPIB).

Keempat, modul disusun berlandaskan pada tiga tahapan sebelumnya. Uraian materi pada modul terdiri dari 3 (tiga) $\mathrm{BAB}$ Kegiatan Pembelajaran yang membahas mengenai: Volume Pekerjaan, Analisa Harga Satuan Pekerjaan, dan Rencana Anggaran Biaya. Melalui ketiga BAB tersebut diharapkan dapat menjadikan peserta didik menerapkan perhitungan $\mathrm{RAB}$ (Rencana Anggaran Biaya) mulai dari perhitungan volume pekerjaan dan analisa harga satuan pekerjaannya.

Tahap develop dilakukan dengan melakukan penilaian terhadap modul yang dikembangkan menggunakan instrumen berupa kuesioner/angket dengan skala Likert. Tahap ini dilakukan dengan dua pengujian yaitu Expert Appraisal dan Development Testing. Validasi dan penilaian expert appraisal modul dilakukan oleh ahli media dan ahli materi yang kompeten di bidangnya. Ahli materi dan ahli media terdiri dari dosen FT UNY jurusan Pendidikan Teknik Sipil dan Perencanaan.

Hasil uji kelayakan modul oleh ahli materi didapatkan analisis butir diadopsi dari kriteria modul yang baik oleh Direktorat Pembinaan Sekolah Menengah Kejuruan
(2013) antara lain aspek self-instruction, aspek self-contained, aspek stand alone, aspek adaptive, dan aspek user friendly. Evaluasi dan validasi ini bertujuan untuk mengetahui kelayakan modul pembelajaran yang telah dikembangkan.

Tabel 1. Persebaran Nilai Validasi Ahli Materi

\begin{tabular}{|c|c|c|c|c|c|c|c|}
\hline \multirow[b]{2}{*}{ No. } & \multirow{2}{*}{ Aspek } & \multicolumn{3}{|c|}{ Frekuensi } & \multirow{2}{*}{$\begin{array}{l}\text { Jumla } \\
\text { h Butir }\end{array}$} & \multirow{2}{*}{$\begin{array}{c}\text { Jumla } \\
\text { h Skor }\end{array}$} & \multirow{2}{*}{$\begin{array}{c}\text { Sko } \\
\mathbf{r} \\
\text { Max } \\
\end{array}$} \\
\hline & & 12 & 3 & 4 & & & \\
\hline 1. & $\begin{array}{l}\text { Self- } \\
\text { Instruc } \\
\text { tion }\end{array}$ & & $\begin{array}{l}1 \\
3\end{array}$ & $\begin{array}{l}1 \\
0\end{array}$ & 23 & 79 & 92 \\
\hline 2. & $\begin{array}{l}\text { Self- } \\
\text { Contai } \\
\text { ned }\end{array}$ & & & 2 & 2 & 8 & 4 \\
\hline 3. & $\begin{array}{l}\text { Stand } \\
\text { Alone }\end{array}$ & & 2 & & 2 & 6 & 4 \\
\hline 4. & $\begin{array}{l}\text { Adapti } \\
\text { ve }\end{array}$ & & & 3 & 3 & 12 & 12 \\
\hline 5. & $\begin{array}{l}\text { User } \\
\text { Friendl } \\
y\end{array}$ & & 8 & 2 & 10 & 32 & 40 \\
\hline & Tot & & & & 40 & 137 & 160 \\
\hline
\end{tabular}

Dari perhitungan tabel di atas didapatkan nilai rerata skor sebesar 3,425. Nilai tersebut selanjutnya digunakan sebagai acuan penetapan kriteria kelayakan. Berdasarkan data validasi ahli materi di atas, rerata skor diperoleh sebesar 3,425 dimana berada pada rentang skor $3,25<X \leq 4,00$. Sehingga dilihat dari aspek materi modul Estimasi Biaya Konstruksi Jalan termasuk ke dalam kategori sangat layak.

Hasil uji kelayakan modul oleh ahli didapatkan analisis butir instrumen diambil dari instrumen penilaian buku teks pelajaran tahun 2014 Badan Standar Nasional Pendidikan. Penilaian modul tersebut terdiri dari tiga kriteria, masing-masing kriteria tersebut terdiri dari a) Ukuran modul; b) Desain sampul modul; dan c) Tata letak isi buku. Evaluasi dan validasi ini bertujuan untuk mengetahui kelayakan modul pembelajaran yang telah dikembangkan. 


\begin{tabular}{|c|c|c|c|c|c|c|c|}
\hline \multirow{3}{*}{ No. } & \multicolumn{7}{|c|}{ Tabel2. Persebaran Nilai Validasi Ahli Media } \\
\hline & \multirow{2}{*}{ Aspek } & \multicolumn{3}{|c|}{ Frekuensi } & \multirow{2}{*}{$\begin{array}{c}\text { Jumlah } \\
\text { Butir }\end{array}$} & \multirow{2}{*}{$\begin{array}{c}\text { Jumlah } \\
\text { Skor }\end{array}$} & \multirow{2}{*}{$\begin{array}{r}\text { Skor } \\
\text { Max }\end{array}$} \\
\hline & & 12 & 3 & 4 & & & \\
\hline 1. & $\begin{array}{l}\text { Ukuran } \\
\text { Modul }\end{array}$ & & 2 & & 2 & 6 & 8 \\
\hline 2. & $\begin{array}{l}\text { Desain } \\
\text { Sampul } \\
\text { Modul }\end{array}$ & 4 & 14 & & 18 & 50 & 72 \\
\hline 3. & $\begin{array}{l}\text { Tata } \\
\text { Letak Isi } \\
\text { Buku }\end{array}$ & 1 & 30 & 3 & 34 & 104 & 136 \\
\hline & To & & & & 54 & 160 & 216 \\
\hline & Rerat: & kor & & & & 2,96 & 4 \\
\hline
\end{tabular}

Tabel3. Pers ebaran Validasi Guru sebagai Pengguna

\begin{tabular}{|c|c|c|c|c|c|c|}
\hline \multirow{2}{*}{ No. } & \multirow{2}{*}{ Aspek } & \multicolumn{2}{|c|}{ Frekuensi } & \multirow{2}{*}{$\begin{array}{c}\text { Jumlah } \\
\text { Butir }\end{array}$} & \multirow{2}{*}{$\begin{array}{c}\text { Jumlah } \\
\text { Skor }\end{array}$} & \multirow{2}{*}{$\begin{array}{l}\text { Skor } \\
\text { Max }\end{array}$} \\
\hline & & $\begin{array}{lll}1 & 2 & 3\end{array}$ & 4 & & & \\
\hline 1. & $\begin{array}{l}\text { Self- } \\
\text { Instruction }\end{array}$ & & 23 & 23 & 92 & 92 \\
\hline 2. & $\begin{array}{l}\text { Self- } \\
\text { Contained }\end{array}$ & & 2 & 2 & 8 & 4 \\
\hline 3. & $\begin{array}{l}\text { Stand } \\
\text { Alone } \\
\end{array}$ & & 2 & 2 & 8 & 4 \\
\hline 4. & Adaptive & & 3 & 3 & 12 & 12 \\
\hline 5. & $\begin{array}{l}\text { User } \\
\text { Friendly }\end{array}$ & & 10 & 10 & 40 & 40 \\
\hline & Tota & & & 40 & 160 & 160 \\
\hline & Rerata: & kor & & & 4 & 4 \\
\hline
\end{tabular}

Dari perhitungan tabel di atas, didapatkan nilai rerata skor sebesar 2,96. Nilai tersebut selanjutnya digunakan sebagai acuan penetapan kriteria kelayakan. Berdasarkan data validasi ahli media di atas, rerata skor diperoleh sebesar 2,96 dimana berada pada rentang skor $2,5<X \leq 3,25$. Sehingga dilihat dari aspek materi modul Estimasi Biaya Konstruksi Jalan termasuk ke dalam kategori layak.

Tahapan uji coba pengembangan (development testing) dilakukan untuk memperoleh tanggapan dari pendidik/guru pengampu mata pelajaran Estimasi Biaya Konstruksi dilihat dari segi materi sebagai pengguna. Analisis butir instrumen kajian sama seperti ahli materi yang diadopsi dari kriteria modul yang baik oleh Direktorat Pembinaan Sekolah Menengah Kejuruan (2013) antara lain aspek self-instruction, aspek self-contained, aspek stand alone, aspek adaptive, dan aspek user friendly.

Validasi materi dilakukan oleh guru SMK Negeri 1 Purworejo. Validasi dilaksanakan pada tanggal 15 Juni 2020. Berikut persebaran nilai validasi yang didapatkan.
Dari perhitungan tabel di atas, didapatkan nilai rerata skor sebesar 4. Nilai tersebut selanjutnya digunakan sebagai acuan penetapan kriteria kelayakan. Berdasarkan data validasi ahli materi di atas, rerata skor diperoleh sebesar 4 dimana berada pada rentang skor $3,25<\mathrm{X} \leq 4,00$. Sehingga dilihat dari aspek materi modul Estimasi Biaya Konstruksi Jalan termasuk ke dalam kategori sangat layak.

Tahap dissemination, terdiri atas: a) Validation testing; b) Packaging; dan c) Diffusion and adaption. Namun tahap validation testing belum dapat dilaksanakan dikarenakan keterbatasan waktu. Untuk tahap packaging, diffusion and adoption dilaksanakan dengan memberikan modul pembelajaran dalam bentuk soft file pada guru mata pelajaran Estimasi Biaya Konstruksi agar nantinya dapat dicetak dalam skala besar baik oleh pihak sekolah maupun oleh peserta didik. Tahap penyebaran dalam kajian ini tidak dapat dilakukan secara luas karena keterbatasan waktu, kemampuan pengkaji dan biaya untuk memproduksi modul dalam skala besar.

Penyusunan modul pembelajaran ini didasari oleh permasalahan yang ditemukan, 
yaitu belum tersedianya bahan ajar untuk siswa, tuntutan Kurikulum 2013 Revisi dan pembelajaran masih bersifat teacher centered sehingga peserta didik kurang mandiri dan adanya ketergantungan terhadap guru dalam belajar maupun menyelesaikan tugas. Terlebih lagi pada mata pelajaran Estimasi Biaya Konstruksi memerlukan banyak latihan soal agar dapat memahami dengan baik. Dengan adanya modul pembelajaran, siswa dapat melaksanakan proses belajar secara mandiri di dalam kelas maupun di luar kelas dan menjawab segala permasalahan tadi. Sehingga dalam kajian ini dikembangkan media pembelajaran berupa modul estimasi biaya konstruksi jalan pada mata pelajaran Estimasi Biaya Konstruksi kelas XI kompetensi keahlian Desain Pemodelan dan Informasi Bangunan SMK Negeri 1 Purworejo.

Model pengembangan yang digunakan dalam kajian ini adalah pengembangan dengan model 4D Thaigarajan dan telah disesuaikan dengan kebutuhan kajian. Tahapan kajian yaitu define (pendefinisian), design (perancangan), develop (pengembangan), dan disseminate (penyebarluasan). Setelah media pembelajaran selesai dibuat, selanjutnya dilakukan uji kelayakan media yang dilakukan oleh ahli materi, ahli media dan guru sebagai pengguna. Hasil dari pengujian kelayakan modul oleh ahli materi, ahli media dan guru sebagai pengguna adalah saran dan masukan yang selanjutnya digunakan menyempurnakan modul yang telah dibuat. Penyempurnaan modul bertujuan agar produk modul yang dikembangkan lebih mudah dipahami oleh siswa dalam proses pembelajaran. Sehingga apabila dikembangkan sesuai dengan prosedur pengembangan, maka akan menghasilkan produk yang bermutu dan layak digunakan sebagai sumber belajar.

Hasil analisis yang diperoleh dari penilaian validator ahli materi untuk modul estimasi biaya konstruksi jalan termasuk dalam kategori sangat layak. Rincian penilaian kelayakan materi pembelajaran modul berdasarkan hasil dari ahli materi adalah sebagai berikut.

Tabel4. Hasil Validasi Ahli Materi Dosen

\begin{tabular}{clcc}
\hline No. & \multicolumn{1}{c}{ Aspek } & Skor Rerata & Kategori \\
\hline 1. & Self-Instruction & 3,43 & Sangat Layak \\
\hline 2. & Self-Contained & 4 & Sangat Layak \\
\hline 3. & Stand Alone & 3 & Layak \\
\hline 4. & Adaptive & 4 & Sangat Layak \\
\hline 5. & User Friendly & 3,2 & Layak \\
\hline & Rerata & $\mathbf{3 , 4 2 5}$ & Sangat Layak \\
\hline
\end{tabular}

Hasil analisis yang diperoleh dari penilaian validator ahli media untuk modul estimasi biaya konstruksi jalan termasuk dalam kategori layak. Rincian penilaian kelayakan materi pembelajaran modul berdasarkan hasil dari ahli materi adalah sebagai berikut.

Tabel5. Hasil Validasi Ahli Media

\begin{tabular}{clcc}
\hline No. & \multicolumn{1}{c}{ Aspek } & Skor Rerata & Kategori \\
\hline 1. & Ukuran Modul & 3 & Layak \\
\hline 2. & $\begin{array}{l}\text { Desain Sampul } \\
\text { Modul }\end{array}$ & 2,78 & Layak \\
\hline 3. & $\begin{array}{l}\text { Tata Letak Isi } \\
\text { Buku }\end{array}$ & 3,06 & Layak \\
\hline & Rerata & $\mathbf{2 , 9 6}$ & Layak \\
\hline
\end{tabular}

Hasil analisis yang diperoleh dari penilaian validator guru sebagai pengguna untuk modul estimasi biaya konstruksi jalan termasuk dalam kategori sangat layak. Rincian penilaian kelayakan materi pembelajaran modul berdasarkan hasil dari ahli materi adalah sebagai berikut. 
Efektivitas Modul Estimasi ... (Sumardjo/ hal. 104-116)

Tabel6. Hasil Validasi Guru Sebagai Pengguna

\begin{tabular}{clcl}
\hline No. & \multicolumn{1}{c}{ Aspek } & Skor Rerata & Kategori \\
\hline 1. & Self-Instruction & 4 & Sangat Layak \\
\hline 2. & Self-Contained & 4 & Sangat Layak \\
\hline 3. & Stand Alone & 4 & Sangat Layak \\
\hline 4. & Adaptive & 4 & Sangat Layak \\
\hline 5. & User Friendly & 4 & Sangat Layak \\
\hline & Rerata & $\mathbf{4}$ & Sangat Layak \\
\hline
\end{tabular}

Setelah dilakukan penilaian kelayakan modul, selanjutnya produk dikemas dalam bentuk modul yang selanjutnya diserahkan kepada guru mata pelajaran Estimasi Biaya Konstruksi SMK Negeri 1 Purworejo supaya dapat dimanfaatkan dalam kegiatan pembelajaran di kelas.

\section{SIMPULAN}

Berdasarkan hasil dan pembahasan dalam kajian ini dapat disimpulkan bahwa pengembangan modul pembelajaran Estimasi Biaya Konstruksi Jalan ini dikembangkan dengan menggunakan metode 4D yang dikembangkan oleh Thiagarajan melalui beberapa tahap, diantaranya: Define (pendefinisian), pada tahap ini dilakukan dua kegiatan yaitu observasi dan wawancara. Dari hasil kegiatan tersebut didapati permasalahan berupa kurang tersedianya sumber belajar pada mata pelajaran Estimasi Biaya Konstruksi khususnya pada materi estimasi biaya konstruksi jalan. Di lain hal itu diperlukannya media pembelajaran yang dapat digunakan di dalam kelas maupun di luar kelas sehingga peserta didik dapat mempelajari dan berlatih mengerjakan soal secara mandiri agar tercapai 6 (enam) kompetensi dasar yang diharapkan.

Design (perancangan), pada tahap ini disusun sebuah modul pembelajaran dalam bentuk draft awal meliputi pemilihan media, format penyusunan, layout dan sampul modul yang menghasilkan rancangan awal modul pembelajaran estimasi biaya konstruksi jalan yang terdiri dari 3 (tiga) bab mencakup: (1) Volume pekerjaan; (2) Analisa harga satuan pekerjaan; dan (3) Rencana Anggaran Biaya. Rancangan modul dilengkapi dengan halaman sampul, halaman prancis, kata pengantar, daftar isi, daftar gambar, daftar tabel, pendahuluan (latar belakang, deskripsi singkat, standar kompetensi, peta konsep, manfaat, tujuan pembelajaran, dan petunjuk penggunaan modul), kegiatan belajar (kompetensi dasar, materi pokok, uraian materi, ringkasan, latihan, dan tes mandiri), post test, tindak lanjut, harapan, glosarium, daftar pustaka dan kunci jawaban.

Develop (pengembangan), pada tahap ini dilakukan validasi modul untuk mengetahui masukan dan saran dari ahli materi dan ahli media guna penyempurnaan modul estimasi biaya konstruksi jalan. Dari langkah ini didapatkan beberapa saran perbaikan modul dari ahli materi yang mencakup: (1) Penyajian modul sudah cukup baik namun runtutan materi yang disampaikan perlu dibuat lebih terstruktur dan sistematis; (2) Penyajian tabel perlu diperjelas dengan bagan alir yang dapat menjelaskan tahapan proses perhitungan; (3) Tabel perhitungan perlu dilengkapi penjelasan data/input dari proses sebelumnya dan kegunaan output yang dihasilkan. Sedangkan saran perbaikan modul dari ahli media mencakup: (1) Indek table dan gambar ditulis berurutan mulai dari bab pertama sampai bab terakhir; (2) 
Halaman landscape sebaiknya disesuaikan dengan posisi tulisan kontennya.

Disseminate (penyebarluasan), pada tahap ini pengemasan dan penyebaran hasil pengembangan modul hanya dilaksanakan dengan memberikan modul pembelajaran dalam bentuk soft file pada guru mata pelajaran Estimasi Biaya Konstruksi agar nantinya dapat dicetak dalam skala besar baik oleh pihak sekolah maupun oleh peserta didik.

Berdasarkan hasil validasi modul estimasi biaya konstruksi jalan diperoleh: (1) Ahli materi, dari lima aspek diperoleh

\section{DAFTAR RUJUKAN}

Ali, M. Laras, J. Heru, T. \& Hartoyo. (2017). Analisa Pengembangan Kurikulum dan Perangkat Pembelajaran Bidang Teknik Listrik untuk Pendidikan dan Pelatihan PT Summarecon Agung. Jurnal.

Amir, A. (2014). Pembelajaran Matematika SD dengan Menggunakan Media Manipulatif. Forum Pedagogi, 6, 72 89.

Arsyad, A. (2011). Media Pembelajaran. Jakarta: PT RajaGrafindo Persada.

BSNP. (2014). Publikasi Badan Standar Nasional Pendidikan, Tahun 2014, tentang Instrumen Modul Teks Pelajaran.

Budijono, A.P. \& Kurniawan, W.D. (2012). Penerapan Modul Berbasis Komputer Interaktif untuk Meningkatkan Kualitas Proses dan Hasil Pembelajaran pada Mata Kuliah Pneumatik dan Hidraulik. persepsi kelayakan sebesar 3,425 dengan kategori sangat layak untuk digunakan sebagai bahan ajar mata pelajaran Estimasi Biaya Konstruksi; (2) Ahli media, dari ketiga aspek diperoleh persepsi kelayakan sebesar 2,96 dengan kategori layak untuk digunakan sebagai bahan ajar mata pelajaran Estimasi Biaya Konstruksi; (3) Guru sebagai pengguna, dari lima aspek diperoleh persepsi kelayakan sebesar 4 dengan kategori sangat layak untuk digunakan sebagai bahan ajar mata pelajaran Estimasi Biaya Konstruksi;

Jurnal Pendidikan Teknologi dan Kejuruan, 21, 106-113.

Depdikbud. (1990). Peraturan Pemerintah RI Nomor 29, Tahun 1990, tentang Pendidikan Menengah.

Depdikbud. (2003). Undang-Undang RI Nomor 20, Tahun 2003, tentang Sistem Pendidikan Nasional.

Ervianto, W.I. (2005). Manajemen Proyek Konstruksi. Yogyakarta: Andi Offset.

Hamalik, O. (2017). Kurikulum dan Pembelajaran. Jakarta: Bumi Aksara.

Hartoyo. (2009). Upaya Meningkatkan Prestasi Melalui Pembelajaran dengan Modul Berbasis Kompetensi. Jurnal Pendidikan Teknologi dan Kejuruan, 18, 61-84.

Ibrahim, B. (2009). Rencana dan Estimate Real of Cost. Jakarta: Bumi Aksara. 


\section{Efektivitas Modul Estimasi ... (Sumardjo/ hal. 104-116)}

Kemendikbud. (2017). Keputusan Direktur Jendral Pendidikan Dasar dan Menengah Nomor: 330/D.D5/KEP/KR/2017, Tahun 2017, tentang Kompetensi Inti dan Kompetensi Dasar Mata Pelajaran Muatan Nasional (A), Muatan Kewilayahan (B), Dasar Bidang Keahlian (C1) Dasar Kompetensi keahlian (C2), dan Kompetensi Keahlian (C3).

Kurniasih, I. \& Sani, B. (2016). Revisi Kurikulum 2013: Implementasi Konsep dan Penerapan. Yogyakarta: Kata Pena.

Mulyatinigsih, E. (2011). Riset Terapan Bidang Pendidikan \& Teknik. Yogyakarta: UNY Press.

Nasution, S. (2006). Asas-Asas Kurikulum. Jakarta: Bumi Aksara.

Nugroho, R.E. \& Suryaningrum. (2018). Estimasi Biaya Konstruksi, Sanitasi, dan Perawatan Gedung. Jakarta: Andi.

Permen PUPR. (2016). Peraturan Menteri Pekerjaan Umum dan Perumahan Rakyat Nomor: 28/PRT/M/2016, Tahun 2016, tentang Analisa Harga Satuan Pekerjaan Bidang Pekerjaan Umum

Prastowo, A. (2015). Panduan Kreatif Membuat Bahan Ajar Inovatif . Yogyakarta: Diva Press.

Pratama, G. N. I. P. (2019, May). Basic communication skill drill in microteching context to improve the teching skills of civil engineering and planning education students, faculty of engineering, Yogyakarta State University. In IOP Conference Series: Materials Science and Engineering (Vol. 535, No. 1, p. 012014). IOP Publishing.

Pratama, G. N. I. P., \& Triyono, M. B. (2015). Peningkatan kualitas pembelajaran prakarya dan kewirausahaan melalui metode CLTSMK. Jurnal Pendidikan Vokasi, 5(3), 313-324.

Sanaky AH, H. (2009). Media Pembelajaran. Yogyakarta: Safiria Insania Press.

Sanjaya, W. (2006). Strategi Pembelajaran Berorientasi Standar Proses Pendidikan. Jakarta: Prenadamedia Group.

Setiawan, M.A. (2007). Belajar dan Pembelajaran. Jakarta: Uwais Inspirasi Indonesia.

Slamet PH. (2011). Peran Pendidikan Vokasi Dalam Pembangunan Ekonomi. Cakrawala Pendidikan, 189-203.

Sugiyono. (2018). Metode Penelitian Penelitian Pendekatan Kuantitatif, Kualitatif dan $R \& D$. Bandung: Alfabeta.

Sukiman. (2012). Pengembangan Media Pembelajaran. Yogyakarta: Pedagogia. 
Efektivitas Modul Estimasi ... (Sumardjo/ hal. 104-116)

Sukmadinata, N.S. (2017). Pengembangan Kurikulum: Teori dan Praktik. Bandung: PT Remaja Rosdakarya.

Suparman, M.A. (2014). Desain Instruksional Modern: Panduan Para Pengajar dan Inovator Pendidikan. Jakarta: Erlangga.

Susanta, G. (2008). Renovasi Rumah Menjadi Rumah Usaha. Depok: Penebar Swadaya.

Susilana, R. \& Riyana, C. (2009). Media Pembelajaran. Bandung: $\mathrm{CV}$ Wacana Prima.

Thiagarajan. (1974). Instructional Development For Training Teachers of Exceptional Children A Sourcebook. Indiana: Indiana University Bloomington.

Triyono, B. M., Mohib, N., Kassymova, G. K., Pratama, G. N., Adinda, D., \& Arpentieva, M. R. (2020). The Profile Improvement of Vocational School Teachers' Competencies. Vysshee obrazovanie $v$ Rossii= Higher Education in Russia, 29(2), 151-158.

Umar, H. (2011). Metode Penelitian untuk Skripsi dan Tesis Bisnis. Jakarta:PT RajaGrafindo Persada.

Utomo, Tjipto. (1989). Peningkatan dan Pengembangan Pendidikan: Manajemen Perkuliahan dan Metoda Perbaikan Pendidikan. Jakarta: Gramedia.
Vembriarto. (1976). Pengantar Pengajaran Modul. Yogyakarta: Paramita.

Wulandari, B., Pratama, G. N. I. P., Hasanah, N., \& Yuniarti, N. (2019, November). Augmented Reality As Android Based Learning Media for Wood Field Laboratory Work. In Journal of Physics: Conference Series (Vol. 1413, No. 1, p. 012035). IOP Publishing.

Yuwono, K.T. \& Suprapto. (2011). Pengembangan Modul Praktikum Mikrokontroler (AVR) Menggunakan Perangkat Lunak Proteus Professional v7.5 SP3. Jurnal Pendidikan Teknologi dan Kejuruan, 20, 21-42. 